Historic, Archive Document

Do not assume content reflects current scientific knowledge, policies, or practices. 


\section{Potatoes Grown Especially for Seed}

No other section produces as Healthy and Vigorous Seed Potatoes as Northwestern New York. Try them and be Convinced.

GET THE BEST.

PURE SEED.

TRUE TO NAME.

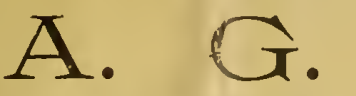

A

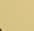

Speclal Discounts to Members of the Grange and Farmers' Exchange. (Oflcers please distribute these Price Lists among Menjers.)
NORTHERN GROWN.

\section{OUR SEED POTATOES.}

WE HAVE a good supply of true stock now in stor", which is very fine, and in good condition. Orders will be broked as received, and shipped in rotation, after danger of freezing is over. We can ship nearly any time between March 15th and June. We assume no responsibility for damage incurred in transit, but we will exercise the greatest care to guard against the sudden cha.lges of temperature. At the LOW RATE here offered, custo uers are expected to pay the charges when sent by freight or express. Our soil is especially adapted to growing smooth, handsome tubers, perfectly free from disease Our location for furnishing Good Seen g⿵人ock is unsurpassed. Cash must accompany order's to secure attention. The following varieties are the best and most pipular now in cultivation. To 4 LL wHO INTEND TO BUY SEED POTATOES we will say that the best potatoes grown in the United States are grown in Western New. York. More potatoos are grown in this town than in any other town in New York State. Western New York took the Sweep Stake Premium for the best exhibit of potatoes at the World's Columbian Exposition. Where our Seed Potatoes have been tested with those grown in Maine and other states, they have excelled in almost every instance. If you have position. possible. We are now shipping in car lots and using refrigerator and produce cars. Write also for price on car fancy eating potatoes for grocer trado, to be loaded in good sacks.

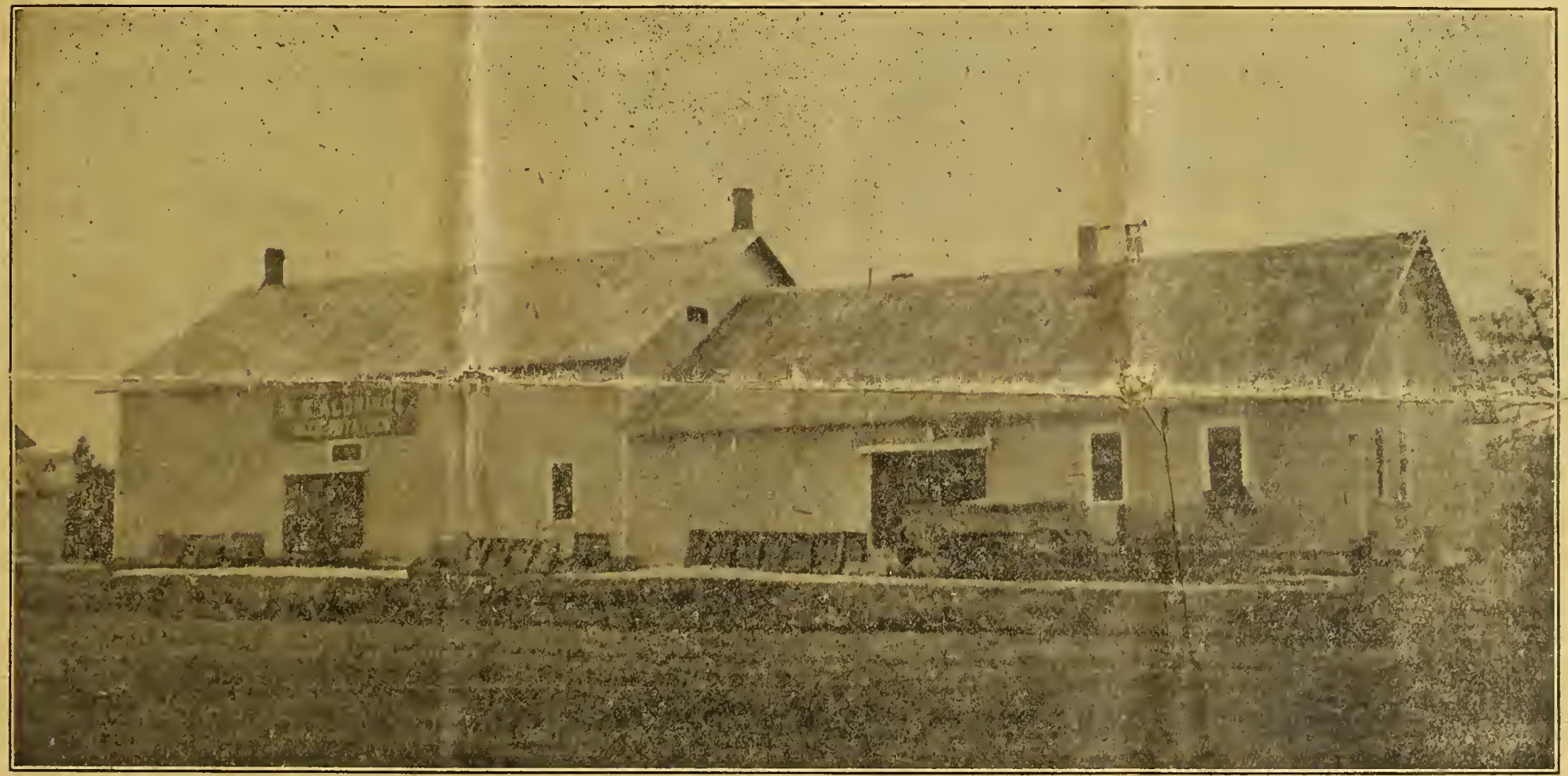

OUR FROST=PROOF STOREHOUSE

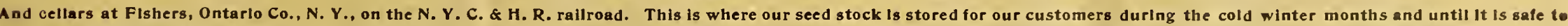
ship out in early spring.

\section{"ORANGE BRAND" EATING POTATOES.}

D

YOU know that some people never hare really good eating potatoes? Let me tell you the reason. Potatoes are loaded in cars by commission men, and it requires from 10 to 15 wagon loads to fll a car are loaded and mixed in one car. How do such.potatoes cook? Some will cook in twenty minutes some in thirty, some in forty, and some never will cook so vou can eat them. We receive many letters ed stock of some one variety grown in warm sandy soil which is especially adapted to growing excellent potatoes that when cooked will be dr, floury and of goed flavor. We are prepared to furnisb families, boarding houses or hotels and want one GROCER in your city or village to keep these on hand. Potatoes in this section are mostly hoed and harvested by machinery, which does away to a great exteni, with hook marks and green ends, and causes much less waste. We ship in barrels or sacks and book no furnishing fancy eating potatoes for the grocery trade. Threc bushels, 180 pounds in each sack.

\section{PURE SEED.}

My potatoes are grown especially for seed purposes, are not to be classed with the common stock handled by commission men. The growing, storing and packing sre under my personal supervisiox, and the ber they are no better on that account, and many times not as good.

\section{HOW TO SEND MONEY.}

Remittances may be made at our risk by either of the following methods, viz.: Postoffec money order draft on New York, Express Company's money order, or by registered letter. Money order office at References:-NATIONAL BANK OF COMMERCE, Rochester, N. Y.: W. B. GALLUP, Merchant, Victor, N. Y.; GEO. FOWLER, Merchant, Fishers, N. Y., MERCANTILE AGENCTEs, and the trade.

\section{A GOOD STOREHOUSE}

Is very important in carrying on the business of growing and selling potatoes tor seed. Potatoes that have been wintered too cold or even too warm, are not goou seed. M

\section{LOCATION.}

Fishers is located in the town of Victor, on the N. Y. C. \& H. R. Railroad, and is in the center of the best potato growing section in New York state. We ship potatoes every season to Maine, Michigan, Wisconsin, Minnesota, and all of the Southern and Middle states: have also shipped to Canada, Mexico and Russia It is generally known tion possess unusual vitality. We have Western Union Telegraph. American Express,
Phone.

\section{TO SALESMEN AND AGENTS.}

We want a good reliable man in each town to sell our Seed Potatoes. Our agents will make special low" prices to Agents, wishing to commence the trade in new scctions where our seed has never been tested. If you can sell I0u nols. this year by a little hard work, you can sell 500 bbls. very easy next year, for one urlal will convince the growers that our Seed Polatoes are the best. There is nothing you can do through the winter and spring months that will pay you as well. Write for agent's prices. Begin the work early and sell your neighvor a barrel of the best pure seed at a lower price than otheit
agents would charge him for one bushel of poor seed. 


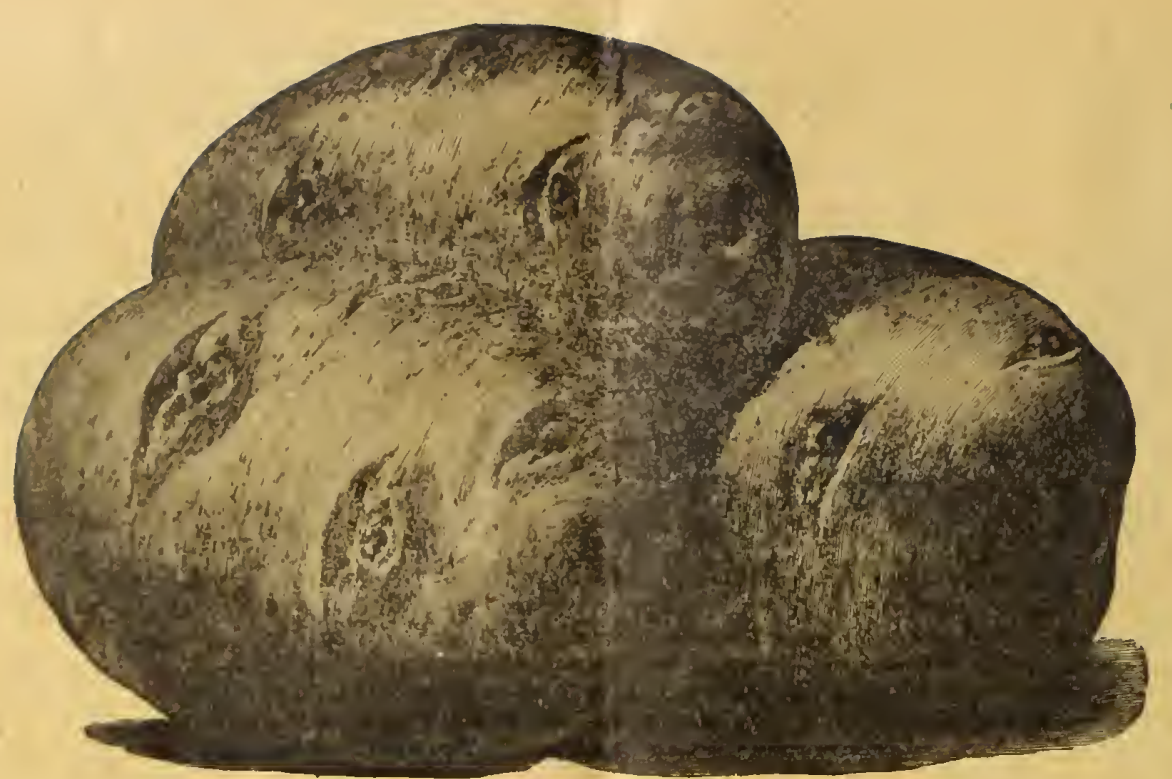

OHIO JUNIOR.

This is a chance seedling. and is in some way reiated to that good old" sort, the "Early Ohio," as it is almost identical with that variety in form and marking of tuber, habit of growth, elc. It is the first and only instance Where the Chio has been reproduced from seed. The tubers are oval.oblong. round at the seed end, with fuli eyes, that are almost even with the surface. It is an excellcnt keeper, of the quailty, and very productive. We prom 10 to 25 cents per bushel more than other varieties.

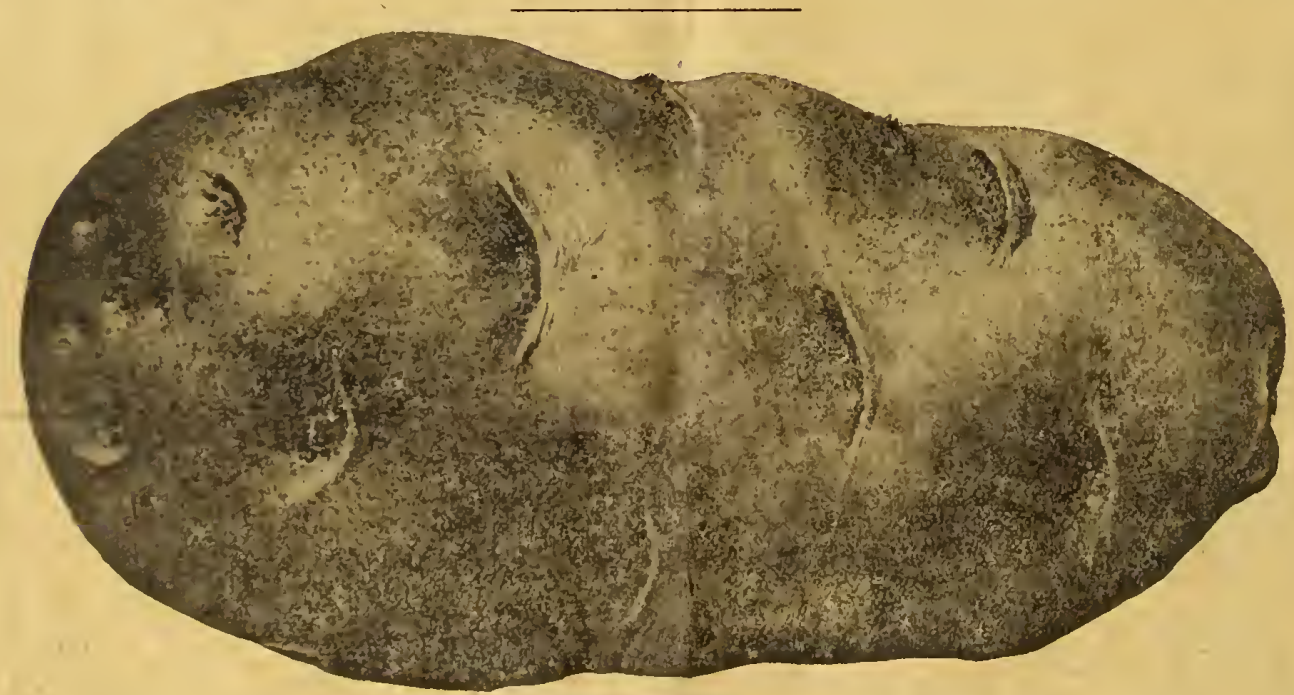

LONGFELLOW.

New, medium late, long, white, with shaliow exes and verysmooth skin. Vines unusually large and branchIng. with many leaves to shade and cover the ground. It produces a great many very 1arge, long, white potatoes potato soll. Often yields 300 bushels per acre.

\section{SATISFIED CUSTOMERS}

I have hundreds of them who write very pleasing letters every season. Please read below what a few of them have to say regarding my 8 EED POTATUES, and give me a chance to please you as well. When you recomthan the natural outburst of honest enthusiasm, there is a reason why every thinking person should investigate. February $22,1912$.
This is about the fifth year I have ordered seed potatoes from you, and I can say I have been well satisfled
with the results.

April 30, 1912 I wish to thank you for sending me sach nice potatoes. They were the finest lot I ever received, and all were much pieased with them. Pleased customers are the best advertisements a man can have.

Potatoes received in good shape and opened up satisfactorily. November 29, 1912. May 6, 1913

Received the potatoes yesterday all O. IK. They scem like nice ones. Thanks to you. My seed potatoes arrived in fine condition. I have always had good results from your A May 20, 1913. Bhape. Thank you for your efforts to get them through.
and on the way, but they are flae and In good
S. A., Dayton, Ohio MR. A. G. A LIRIDGE,- February 15, 1910.

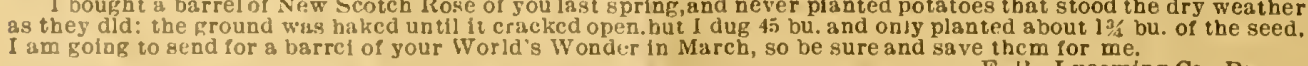

The seed potaines that you hent us-State of Malne-were very satisfactory. We have just finished planting and we did not find any waste at all. We found them as represented and of excellent quallty. II we are in nee
of any inother seasnn, wc will give you our order. A. G. AlDRadie-Dear Sir-
Potatoes arrived in fine shape and am pleased very much with them. Wish you success in business. 1911 .
Your potatoes at hand, recelved the 3rd. Are nice seed in J. D. M., Armstrong Co., Pa.

\section{KNOCK-OUT}

A very promising new round white iate main crop variety now oflered for the tirst time, and stock will he ling I noticed espectally that the tubers were all of good marketsible potatocs. very handsome in shape and color of skin. Piace your orders early for this variety.

\section{NEW CENTURY.}

New. One of the best fate main crop round white varletles now in cultlva. tion, being very uniform in shapc, smooth clear skin, sound, and of excellent cooking quality. This new sort is very productive, vines largc and branching. and a large number of fine, sound tuhers of just the right slye and shope in
each hill. We are pleased to recommend this new varlety to our best custom-

\section{EUREKA.}

Extra eariy, and a coming favorite. Although a chance seeding, it is very

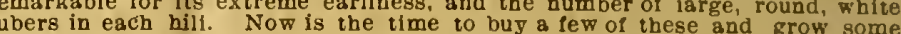
extra eariy potatoes to sell to your neighbors.

\section{GOOD SEED POTATOES.}

For many years, I have made seed potato growing a spectal study and have grown thousands of bushels for my customers, also for other seedsmen, and have shipped direct to thelr trade from Fishers. I have always lived on a farm and take great interest in planting and caring for the crops as well as harvesting same. During this time, I have tested hundreds of old and new varieties as to eating and cooking qualities, productiveness, time of ripening, líability to dis. ease. and suitable soil. This experimenting has been carried on in severai different torns and counties and by it I have learned that the potato that will do well on one kind of soll, may not do well at all in another place on another kind of soll. A potato that may yleid large crops on one farm, may not do weli at all on the adjolning farm. This is something that can only be learned irom experience. We cannot lay down a rule that wouid be of any value when applied to all cases, but each man must learn from experience what kind of potato is most suitable for his soll and market. I am very particular about selecting and planting my seed, also in storing same for the winter senson. My storehouse is so arranged that ail seed is graded by daylight before it is shipped out in spring. I expect by fair and honest dealing to gain and retain a part of your valued patronage, and hope that you will be able to proflt by my experience to the extent that yiou procure seed that will produce the best and earlicst Dotatoes on the market, aiso the best late main crop varieties. I hope you will look this catalogie over carefully, and let me know what you require for planting, next spring. I want to get acquainted with you. Write me a letter or postal and telf me just how many sacks or barrels you will need, and I wlif answer you promptly with lowest possible prices for my best Northern Grown Seed Potatoes. You want the best, for they will be sure to make you a good profit. Write me. A. G. ALDRIDGE.

\section{NATURAL POTATO SOIL.}

Our Seed Potatoes are grown on the best and most natural potato soil in Westera Ne' York. Potatoes have been grown here extensively for over firy years and during that time there has never been a crop failure. Our soli is
and loam, and many of our best Potato Farms are quite rolling and hiliy.

\section{A CHANGE OF SEED} From one soli to another often doubies the yieid, and improves the quality of
the potatoes. Don't plant that old worn out seed any fonger. but get something new and saleable.

\section{FARIY ORDERS.}

We do not hesitate to advise our customers to piace their orders eariy, as good seed stock will be sure to be higher at spring time, and those who order seed.

A. G. ALDRIDGr-Dear Sir:- $\quad$ May 8, 1911. Received the potatoes all $\mathrm{O}$. K. and was very much pleased with them. Wil know where to look for good seed potatoes when I want any more. Please ac-

MR. A. G. ALDKIDGE,- $\quad$ January $12,1910$.

A. G. ALDKIDGE,-
Your seed has given entire satisfaction every time I have ordered from you.
A. M., Rockbridge Co., Va.

Mr. A. G. ALDRIDGE,-
Your sted potatoes have always done well for me, in fact, I have never had $17,1910$.
F. McC. Westchester Co., N. Y. others do as well.

MR. A. G. ALDRIDGE-Dear Sir:- $\quad$ April 29, 1911. We receiverl your potatoes in good shape. They were flne potatoes. If
need any more I wlll bend'to you.

MR. A. G. ALDRIDGE-Dear Sir:- April 25, 1911. Find enclosed money order for 119 . Plcase ship as soon as you can as we have all our own seed planted. In ways have good luck with your seed potatocs. T. K., Alhany Co., N. Y.

POTATO CUTS used in this Catalog are made from photos of the potatoes taken from our Cellars. 